This item is the archived peer-reviewed author-version of:

Conflicts of laws in proceedings before the European Patent Office

\title{
Reference:
}

Beck Michaël.- Conflicts of law s in proceedings before the European Patent Office

International review of intellectual property and competition law - ISSN 0018-9855 - 48:8(2017), p. 925-952

Full text (Publisher's DOI): https://doi.org/10.1007/S40319-017-0643-5

To cite this reference: https://hdl.handle.net/10067/1470880151162165141 


\section{Conflicts of Laws in Proceedings before the European Patent Office}

Michaël Beck (University of Antwerp, Prinsstraat 13, B-2000 Antwerpen, Belgium; the author is a European patent attorney and a $\mathrm{PhD}$ researcher, preparing a series of articles regarding conflicts of laws pertaining to patents as objects of property)

The corresponding author can be reached at following coordinates:

- michael.beck@uantwerpen.be

- $\quad$ T. +32476444734

- F. +3216200621

\section{$\underline{\text { Abstract }}$}

The European Patent Convention (EPC) establishes a common system of law for the grant of European patents. A European patent is often equated to a "bundle of national patents", as far as questions of applicable law are concerned. On closer scrutiny, the applicable conflict-of-laws rules for the various issues that are left to national law by the EPC differ substantially, and many do not fit the "bundle" analogy. This article presents a summary of the legal framework pertaining to conflicts of laws in proceedings before the European Patent Office (EPO), and reviews the state of affairs in the case law of the EPO.

In the first section, the various sources of "EPC law" are identified. Next, the situation in the field of patent infringement is discussed, as an archetype of a "clean" separation between EPC law and national law. The following three sections discuss areas where conflicts of laws are most abundant: existence and capacity of (legal) persons, entitlement to patent applications, and entitlement to priority. In the concluding section, an attempt is made to derive some general rules from the case law in these areas.

Keywords: European Patent Convention, Private International Law, Property Law, Paris Convention 


\section{$\underline{1 . \text { Introduction }}$}

The European Patent Convention (EPC) ${ }^{1}$ contains elaborate provisions about the procedure leading up to the grant of a European patent and the substantive requirements that European patent applications and European patents must meet. These provisions have direct effect and thus provide full harmonization of the specific domains to which they pertain. However, when the EPC was drafted, many other issues were deliberately left to national law, which inevitably leads to questions of demarcation and identification of the applicable national law ${ }^{2}$.

In common parlance, the European patent is often equated to a "bundle of national patents", and certain questions of private international law can indeed be resolved correctly on the basis of that analogy ${ }^{3}$. On closer scrutiny, the applicable conflict-of-laws rules and international jurisdiction rules for the various issues that are left to national law by the EPC differ substantially, and many do not fit the "bundle" analogy.

From the point of view of the European Patent Office (EPO), the European patent application and the European patent as objects of property primarily embody the right of the applicant or proprietor to act in proceedings before the EPO, and it is immediately clear that the "bundle" analogy is too unwieldy a tool to establish party status. Hence, especially in the realm of property law, other conflict-of-laws approaches than the "bundle" analogy are necessary. A systematic investigation of these approaches is called for because the choice can impact the outcome of the legal issues concerned, which can lead to situations where a party loses the ability to exercise the rights it expected to have.

This article presents a summary of the legal framework of conflicts of laws in proceedings before the EPO, and reviews the state of affairs in the case law of the EPO. In the first section, the various sources of "EPC law" are identified. Next, the situation in the field of patent infringement is discussed, as an archetype of a "clean" separation between EPC law and national law, followed by three sections discussing the major areas in which conflicts of laws are most abundant, all of which (directly or indirectly) involve property law. In the concluding section, I present some general rules that can be derived from the case law in these areas.

\footnotetext{
${ }^{1}$ Convention on the Grant of European Patents (European Patent Convention) of 5 October 1973 as revised by the Act revising Article 63 EPC of 17 December 1991 and the Act revising the EPC of 29 November 2000.

${ }^{2}$ In this article, the term "conflict of laws" is used to designate the problem of determining the law applicable to a particular legal issue. Wherever the problem of international jurisdiction is addressed, this will be mentioned separately.

${ }^{3}$ Art. 2(2) EPC.
} 


\section{Sources of Law}

Where the EPC has explicit provisions that can be applied to a particular legal issue, other sources of law (notably case law and legal literature) only play a secondary role. This article is concerned with situations where the EPC is silent on an issue, and national law may have to be applied. It must be emphasized, however, that not every issue on which the EPC is silent must be resolved by applying national law. Procedural issues, including issues of evidence, are normally dealt with by the law of the jurisdiction in which the proceedings are conducted (lex fori $\left.{ }^{4}\right)$, i.e. "EPC law", which may have to be established by the EPO with reference to general legal principles or case law, or by applying other provisions of the EPC by analogy. Substantive issues may be resolved either by applying the lex fori (again to be established as indicated above) or by applying a particular national law, in accordance with the relevant conflict-of-laws rule.

The explicit conflict-of-laws provisions in the EPC are few and far between. The travaux préparatoires ${ }^{5}$ provide a clear indication that this is a consequence of the contracting states' original intent not to burden the EPO with applying national law ${ }^{6}$. Hence, when conflicts of laws occur in proceedings before the EPO despite this intent, the EPO has to resort to other sources of law to find the applicable conflict-of-laws rule.

\subsection{General Legal Principles}

The Enlarged Board of Appeal recognizes that "general legal principles are a recognised source of legal information and can help in the interpretation of written law"'. In practice, there is a thin line between "interpreting written law" and filling the gaps left by the legislator. This is most visible in the partial codification of this principle in art. $125 \mathrm{EPC}$, which determines that in the absence of procedural provisions in the EPC, the EPO takes into account "the principles of procedural law generally recognised in the Contracting States". Hence, even if conflict-of-laws rules are not necessarily "procedural provisions" in the sense of that article ${ }^{8}$, conflict-of-laws principles common to the contracting states could serve as a subsidiary source of law under the broader principle stated by the Enlarged Board of Appeal.

\footnotetext{
${ }^{4}$ I will adhere to the tradition in the field of private international law of using Latin terms when referring to the law applicable to a particular legal issue in an abstract way.

${ }^{5}$ Made available by the EPO at www.epo.org/law-practice/legal-texts/archive/epc-1973/traveaux.html (sic).

${ }^{6}$ Haertel 1962, p. 10; Govt. of the Federal Republic of Germany 1973, p. 184.

${ }^{7}$ EBoA 24 June 1987, G 1/86 (Voest-Alpine), para 12, ECLI:EP:BA:1987:G000186.19870624.

${ }^{8}$ They are not mentioned as such in the travaux préparatoires, nor in standard reference works such as Visser 2016 or Stauder and Luginbühl 2013.
} 
While the EPO is not subject to EU law, and the Rome regulations ${ }^{9}$ therefore do not directly apply to conflicts arising in proceedings before the EPO, the content of these regulations represents principles generally recognized in the EU member states. As these make up the majority of the EPC contracting states, the content of the Rome regulations could also be considered as general principles of the EPC contracting states. For example, in the field of obligations, it could be argued that the rule that obligations are governed by the law of the country with which they are most closely connected ${ }^{10}$, has the status of a general legal principle in the aforementioned sense ${ }^{11}$.

In the field of property law, the reliance on generally recognized legal principles to arrive at conflict-of-laws rules is considerably more difficult. For tangible goods, the traditional approach is that issues of property law are dealt with by the law of the country where the goods are situated (lex rei sitae), but that connecting factor has no unique counterpart in the case of intangible goods. In addition, the matter is further complicated by significant differences in substantive property law, which influence the characterization of property law issues, which in turn affects the outcome of a conflict-of-laws analysis.

Two major dividing lines separate the Western legal systems when it comes to transfer of property: on the one hand there is the distinction between tradition systems and consensual systems, and on the other hand there is the distinction between causal systems and abstract systems $^{12}$. Tradition systems are characterized by the fact that the act of transfer is considered as a legal act distinct from the underlying contract (the causa traditionis). In a conflict-of-laws analysis of a property transfer, the distinction made by tradition systems reveals the possibility of applying different laws to the causa and to the transfer (Spaltungstheorie), rather than letting the law designated for the causa govern the transfer as well (Einheitstheorie) ${ }^{13}$. Given these different possible points of view regarding the law(s) governing a contractual transfer of property, it is not possible to identify a common "principle of procedural law generally recognized in the contracting states".

\footnotetext{
${ }^{9}$ Regulation (EC) no. 593/2008 of the European Parliament and of the Council of 17 June 2008 on the law applicable to contractual obligations (Rome I); Regulation (EC) no. 864/2007 of the European Parliament and of the Council of 11 July 2007 on the law applicable to non-contractual obligations (Rome II).

${ }^{10}$ Consideration 15 of Rome I; consideration 18 of Rome II.

${ }^{11}$ This approach was taken, with explicit reference to the Rome I Regulation, in Opp. Div. 31 May 2013, concerning EP 09000013.4, at 2.1.3 (appeal pending).

${ }^{12}$ Hinterlegger and van Vliet 2012.

${ }^{13}$ Drexl 2005, p. 173; Mankowski 2009, pp. 44-46; Metzger 2013, Article 3:501, pp. 270-271.
} 


\subsection{Case Law}

The EPO's case law is particularly important in view of the succinct nature of the EPC and the limited opportunities for legislative intervention ${ }^{14}$. While the EPO does not adhere to a strict stare decisis doctrine, it nevertheless accords significant weight to precedents of the Boards of Appeal, in application of the principle that "similar situations shall not be treated differently unless differentiation is objectively justified" ${ }^{15}$.

In practice, decisions of the Boards of Appeal attain precedential value by their inclusion in the Guidelines established under art. 10(2)(a) EPC (binding in principle on the first-instance divisions) and by the obligation of the Boards of Appeal to motivate any deviations from precedents ${ }^{16}$. By their nature, the decisions of the Enlarged Board of Appeal, which resolve deviating bodies of case law on particular issues, enjoy the highest degree of authority ${ }^{17}$.

The case law of the Boards of Appeal of the EPO is of particular interest for the present discussion in two respects: firstly, as a source of judicially developed conflict-of-laws rules, and secondly, as a source of substantive law in those cases where the conflict-of-laws rules - or the lack thereof - require the application of "EPC law".

\section{Patent Infringement}

In the domain of infringement, the separation between the EPC and national law is at its clearest. As it was never the intention of the EPC contracting states to transfer jurisdiction over infringement claims to any of the organs of the EPO, the existing rules on international jurisdiction have remained unchanged in this domain ${ }^{18}$.

The EPC explicitly provides the necessary conflict-of-laws rules: not only does it state that any infringement of a European patent is dealt with by national law ${ }^{19}$, but it also clarifies that the relevant law is the respective national law of each of the states for which the patent is granted ${ }^{20}$.

\footnotetext{
${ }^{14}$ All cases cited in this article can be found via the EPO's case law search engine at www.epo.org/lawpractice/case-law-appeals/advanced-search.html. In addition, selected case law is published in the Official Journal of the EPO, and in the regularly updated Case Law of the Boards of Appeal of the European Patent Office. In the footnotes of this article, the Boards of Appeal will be referred to with the abbreviations EBoA (Enlarged Board of Appeal), LBoA (Legal Board of Appeal), and TBoA (Technical Board of Appeal). Full case information is provided with the first citation; subsequent citations will refer to the case number only.

${ }^{15}$ EBoA G 1/86, para 13, quoting ECJ 810/79.

${ }^{16}$ Art. 20 Rules of Procedure of the Boards of Appeal.

17 Art. 21 Rules of Procedure of the Boards of Appeal.

${ }^{18}$ It is clear from the preamble of the EPC and the wording of art. 1 that the contracting states only desired a single procedure for the grant of patents and standard rules governing patents so granted.

${ }^{19}$ Art. 64(3) EPC.

${ }^{20}$ Art. 2(2) EPC.
} 
Hence, in matters of patent infringement, national courts apply national law, and the EPO does not get involved.

Over the past few years, the CJEU has had to clarify some of the finer points of the rules of international jurisdiction over patent infringement disputes under the Brussels I regime, mostly regarding cross-border actions, but the disputes rarely center on the demarcation between the EPC and national law. There is no reason to expect that this will drastically change when the Unified Patent Court (UPC) assumes the jurisdiction presently exercised by national courts; the relevant "national law" will then be the harmonized provisions laid down in art. 25-29 of the Agreement on a Unified Patent Court (UPCA) ${ }^{21}$, but the clear demarcation between the provisions of the UPCA and those of the EPC will remain.

The Enlarged Board of Appeal of the EPO has had an opportunity to rule on the demarcation between national law and the EPC regarding the scope of protection of a European patent. In opposition proceedings, the EPO must verify that amendments proposed by the proprietor do not extend the protection conferred by the patent ${ }^{22}$. While a discussion of the extent of protection is normally part of an infringement analysis carried out by a national court and at least partly determined by national law, the Enlarged Board of Appeal has held that the issue of extension of the scope of protection must be judged without consideration of the national laws of the contracting states in relation to infringement ${ }^{23}$. To arrive at this result, the Enlarged Board of Appeal considered that while the "rights conferred by the patent" are determined by national $\operatorname{law}^{24}$, the "protection conferred by the patent" is determined by the terms of the claims in accordance with the $\mathrm{EPC}^{25}$. While this choice of wording may make the distinction sound artificial, it expresses a real difference between the role of the EPO when applying EPC law to guard the allowable scope of patent claims, and the role of national courts when applying national law to determine the rights that the patent holder can enforce.

It follows from the above that the intended separation between the EPC and national law is clear and effective, and that the EPO can carry out its duties without having to deal with questions of infringement under national law.

\footnotetext{
${ }^{21}$ Agreement of 19 February 2013 on a Unified Patent Court, OJ 2013 C 20, p. 175. This treaty is part of the "EU Patent Package", along with EU Regulations 1257/2012 and 1260/2012, which establish a European patent with unitary effect.

${ }^{22}$ Art. 123(3) EPC.

${ }^{23}$ EBoA 11 December 1989, G 2/88 (Friction Reducing Additive), ECLI:EP:BA:1989:G000288.19891211.

${ }^{24}$ Art. 64(1) EPC: the concrete exclusive rights of the proprietor are determined by national law, soon to be harmonized, for the participating states, by the Agreement on a Unified Patent Court.

${ }^{25}$ Art. 69 EPC.
} 


\section{$\underline{\text { 4. Existence and Capacity of (Legal) Persons }}$}

Any judicial body may be confronted with issues regarding the capacity (and existence) of the persons acting as parties in proceedings before it or the capacity of the persons representing such parties, and the Boards of Appeal of the EPO are no exception. This is an area in which the EPC does not provide any conflict-of-laws provisions, but where the case law has developed in a consistent way.

\subsection{Professional Representatives}

The capacity of professional representatives acting before the EPO may have to be determined by the EPO in the context of a request to interrupt the proceedings under Rule 142(1)(c) EPC. As early as 1985, the Legal Board of Appeal explained that "the legal incapacity of a professional representative ... concerns his incapacity to carry out professional work on behalf of a client. Since there is a unified European profession of representatives before the EPO, there has to be a unified standard of judging such legal incapacity ..."26 The Board further held that this issue is “completely separate from any question of a representative's legal incapacity to manage his own personal affairs", which would be governed by the national law of his nationality or domicile. Hence, the legal capacity of professional representatives is a matter of autonomous, unified EPC law, which is to be applied by the EPO taking into account, where necessary, "general principles of national law"27.

\section{2. "Any natural or legal person"}

The EPC states that a European patent application may be filed by "any natural or legal person, or any body equivalent to a legal person by virtue of the law governing it" ${ }^{\text {,2 }}$. Likewise, "any person" may give notice to the EPO of opposition to a granted European patent ${ }^{29}$. These provisions regulate the minimal requirements that must be met for a party to have standing (locus standi) before the EPO, a matter which is of a procedural nature and therefore governed by the lex fori. Whether a person actually meets these minimal requirements laid down by EPC law may require determinations to be made concerning the person's existence and capacity.

\footnotetext{
${ }^{26}$ LBoA 1 March 1985, J 900/85 (Interruption of proceedings), headnote and extracts published in Official Journal of the European Patent Office, 1985, 159, ECLI:EP:BA:1985:J090085.19850301; in the same sense, LBoA 4 November 1986, no. J 0901/86 (Professional representative/Legal incapacity), headnote and extracts published in Official Journal of the European Patent Office, 1987, 528, ECLI:EP:BA:1986:J090186.19861104.

${ }^{27}$ LBoA 6 April 2000, J 5/99 (Unterbrechung), ECLI:EP:BA:2000:J000599.20000406; LBoA 17 May 2000, J 7/99 (Heavy-duty power), ECLI:EP:BA:2000:J000799.20000517; EPO 2013, p. 536.

${ }^{28}$ Art. 58 EPC.

${ }^{29}$ Art. 99(1) EPC.
} 
Regarding such issues pertaining to the existence and capacity of persons to act in proceedings before the EPO, the EPO considers itself competent to make its own determinations without resorting to judgments of national courts. This jurisdiction appears to follow from the EPO's jurisdiction over the main proceedings.

In contrast to the position taken with respect to professional representatives, the EPO has interpreted the silence of the EPC on matters of existence and capacity of persons acting as parties as an indication that national law applies to these issues ${ }^{30}$; this position has been motivated by the fact that the interest in the application or patent, which is being pursued by the applicant or the proprietor, is an interest in property ${ }^{31}$. The EPO has thus declared national law to be applicable in cases concerning a party's capacity to act in proceedings before the EPO in the light of pending bankruptcy proceedings ${ }^{32}$ and of serious medical conditions ${ }^{33}$, and in cases concerning the capacity to be a party to a transaction involving a European patent application ${ }^{34}$. The Enlarged Board of Appeal has reiterated that the legal personality of a named entity under the EPC is decided on the same basis as before national courts, i.e. "the capacity to sue or to be sued in its own name and on its own account" ${ }^{\prime 35}$. This capacity to sue is said to be assessed on the basis of the relevant national civil procedural law, and the loss of such capacity due to liquidation following bankruptcy proceedings has immediate effect on party status before the $\mathrm{EPO}^{36}$. The choice of a national law to deal with these issues appears to be straightforward, which so far has led to consistent decisions of the EPO: the EPO consistently applies the law of the country of which the person is a national or under the laws of which the legal person is organized.

\subsection{Dissolution}

As a corollary of its competence to determine whether a legal entity exists, the EPO must also be competent to decide whether such a legal entity has ceased to exist. A notable decision on the

\footnotetext{
${ }^{30}$ In a strict interpretation, art. $58 \mathrm{EPC}$ only provides an explicit reference to national law for the question of "equivalence to a legal person".

${ }^{31}$ EPO 2013, p. 535.

${ }^{32}$ LBoA 21 May 1987, J 903/87 (Consolidation), OJ 1988, 177, ECLI:EP:BA:1987:J090387.19870521; TBoA 25 July 2000, no. T 353/95 (Appeal terminated/ALTMANN), ECLI:EP:BA:2000:T035395.20000725.

${ }^{33}$ R. 142(1)(a) EPC and J 903/87.

${ }^{34}$ Visser 2016, p. 153, referring to J 900/85, para 9; Almer 2013, pp. 393-394.

${ }^{35}$ EBoA 18 February 2002, G 3/99 (Admissibility of joint opposition or joint appeal/HOWARD FLOREY), ECLI:EP:BA:2002:G000399.20020218.

36 TBoA 22 February 2007, T 477/05 (Scherenhubtisch/GEISLER), ECLI:EP:BA:2007:T047705.20070222; TBoA 8 March 2007, T 480/05 (Scherenhubtisch/HECKERT GMBH), ECLI:EP:BA:2007:T048005.20070308.
} 
topic of dissolution of legal entities is G 1/13 of the Enlarged Board of Appeal ${ }^{37}$. The underlying facts included an English company filing an opposition against a European patent, and subsequently having its registration deleted, thereby ceasing to exist. This situation had gone unnoticed by the patent proprietor and the opposition division during the course of the firstinstance proceedings, and the company was still not in existence when it lodged an appeal against the decision rendered by the opposition division. When this was discovered, the Board of Appeal was asked to rule on the admissibility of the appeal. As the company's registration was later reinstated by an English court, a measure which revived the company with retroactive effect under English law, the Enlarged Board of Appeal had to determine whether the retroactive revival could heal the lack of capacity to act at the time of filing of the appeal.

As recalled by the Enlarged Board of Appeal, legal entities which do not exist cannot bring or take part in proceedings ${ }^{38}$. Enunciating the precedent-based conflict-of-laws rule for matters of this kind, the Enlarged Board held that it is a clearly established principle under the EPC that national law should be referred to in order to determine whether a legal entity exists or has ceased to exist, and has capacity to act ${ }^{39}$. The Enlarged Board went on to explore the interface between the EPC and national law, clarifying that national law does not trump or overrule the $\mathrm{EPC}^{40}$. The limits on the extent to which the EPO should follow national law, are determined by the fact that transactions made by parties under national law cannot have the effect of conferring onto one of the parties a procedural right vis-à-vis the EPO that the EPC does not recognize. After an analysis of the interests of the parties in the case and the general public, the Enlarged Board concluded that respecting the retroactivity of the revival of the company under UK law ${ }^{41}$ is "not inconsistent" with the procedural rules of the EPC.

The conflict-of-laws rule laid down in G 1/13 has been applied by analogy in subsequent cases. In $\mathrm{T}$ 1458/12, the continuous existence of a legal entity that had undergone a "cross-border transfer of jurisdiction" from the British Virgin Islands to the Republic of Mauritius was recognized on the basis of national law; the national laws of both the British Virgin Islands and

\footnotetext{
${ }^{37}$ EBoA 25 November 2014, G 1/13 (Fischer-Tropsch Catalysts/SASOL TECHNOLOGY II), ECLI:EP:BA:2014:G000113.20141125.

${ }^{38}$ Reference is made to $\mathrm{T} 353 / 95$, para 2.

${ }^{39} \mathrm{G} \mathrm{1/13}$, para 6, with reference to TBoA 17 June 2004, T 15/01 (Mystery Swine Disease/SDLO), para 9, and G 3/99, para 9 .

${ }^{40} \mathrm{G} 1 / 13$, para 16.4 .

${ }^{41}$ The decision of the Board of Appeal explicitly refers to "the law of the United Kingdom", which disregards the federal nature of the UK legal order; in fact, the relevant law is English law (which happens to have been laid down in a statute that applies in the entire United Kingdom).
} 
the Republic of Mauritius were applied as required by the case ${ }^{42}$. In R 17/14, the Enlarged Board of Appeal upheld decision T 291/10, citing art. 58 EPC and G 1/13 to justify the application of national law to determine whether an Austrian Einzelunternehmer (single-person firm) has a legal personality distinct from the natural person conducting the business.

\subsection{Analysis}

The application of the law of the country of which the person is a national to issues of existence and capacity of a party can be seen as a defendable modern application of the age-old "personal statute" rule ${ }^{43}$. In this respect, it should be noted that the reference to national "civil procedural law" in some of the cited decisions appears to be an unfortunate choice of wording ${ }^{44}$. The relevant national law pertaining to (legal) persons, which is in fact being applied, is suited to follow a person into whichever jurisdiction he may venture as this person's proper "personal statute", while national civil procedural law is only linked with a single national jurisdiction and cannot overrule the procedural provisions of EPC law.

It seems logical to extend the "personal statute" rule to legal persons by referring to the laws of the country under the laws of which such legal persons are organized. However, it is debatable whether the law under which a legal person is organized is correctly chosen as "the law governing the legal person" in the sense of the EPC. There is certainly no common principle on this point among the EPC contracting states, as some adhere to the "seat of incorporation theory" 45 while others adhere to the "real seat theory" 46 . The "real seat theory" has lost some ground in the wake of certain ECJ decisions concerning the freedom of establishment ${ }^{47}$, but it has not disappeared ${ }^{48}$. By substantiating its conflict-of-laws rule in G 1/13 with reference to the statement that "[legal] entities such as companies exist only by virtue of the national legal system which governs their incorporation, subsequent existence and cessation", the Enlarged

\footnotetext{
42 The decision further cites TBoA 12 June 2014, T 786/11 (SDU discarding/INNOVATIVE SONIC), ECLI:EP:BA:2014:T078611.20140612, and TBoA 19 November 2014, T 2330/10 (Handling timers after an RLC reset/INNOVATIVE SONIC), ECLI:EP:BA:2014:T233010.20141119, which comprise express references to the BVI Business Companies Act 2004 and the Mauritius Companies Act 2001.

${ }^{43}$ According to von Savigny, who partly incorporated the personal statute rule in his own conflict-of-laws theory, the statutes theory can be traced back at least to $14^{\text {th }}$ century jurist Bartolus de Saxoferrato. Von Savigny 1849, p. 122 and p. 134.

44 T 477/05; T 480/05.

${ }^{45}$ E.g., England, see Briggs 2013, pp. 367-373.

${ }^{46}$ E.g., Belgium, see art. 110 Code of Private International Law.

${ }^{47}$ ECJ C-212/97, Centros Ltd v Erhversus-og Selkabssyrelsen [1999], ECLI:EU:C:1999:126; ECJ C-208/00, Überseering BV v Nordic Construction Company Baumanagement GmbH [2002], ECLI:EU:C:2002:632; ECJ C167/01, Kamer van Koophandel en Fabrieken voor Amsterdam v Inspire Art Ltd. [2003], ECLI:EU:C:2003:512. ${ }^{48}$ Vlas 2009, para 144; Borg-Barthet 2013; ECJ C-210/06, Cartesio Oktató és Szolgáltató bt. [2008], ECLI:EU:C:2008:723; ECJ C-378/10, VALE Építési kft. [2012], ECLI:EU:C:2012:440.
} 
Board seems to ignore the fact that different views are possible as to which national legal system governs the existence of a given corporation. Even if there was no connecting factor to any other national law than English law in that case, the lack of specificity in the Enlarged Board's reasoning leaves the precedential rule open to different interpretations in future cases.

Finally, it must be noted that it is debatable whether the Boards have drawn the demarcation line between EPC law and national law at the most desirable place. In G 1/13, the Enlarged Board could for example have held that once a company ceases to exist under the governing national law, its procedural standing before the EPO disappears, and that such lack of standing irrevocably renders any putative acts performed by the ex-company void as a matter of procedural EPC law. Instead, it chose to let procedural standing follow the fate of the company's existence under national law, even if the existence is governed by rules that have retroactive effect. This particular demarcation is a policy choice, and not merely an automatic consequence of applying a pre-existing conflict-of-laws principle, despite the fact that the Enlarged Board places "the general principle that such issues are the exclusive concern of national law" at the basis of its decision ${ }^{49}$. The actual question the Enlarged Board had to answer is not "whether any limits should be set on ... deference to national law" law, which as the lex fori governs all procedural matters, should consider procedural acts by a then no longer existing but subsequently revived entity to have been validly made. The result of the Enlarged Board's choice is that parties in proceedings before the EPO may end up having to research the arcane details of the law governing legal persons in any country of the world to determine whether a counterparty that has undergone a dissolution nevertheless validly exists for the purposes of conducting proceedings before the EPO, a complication which could have been avoided.

\section{$\underline{\text { 5. Entitlement to the Application }}$}

\subsection{Overview}

At first sight, the EPC provides an equally hermetic separation between the EPC and national law in the domain of property law as it does in the domain of patent infringement. The separation is deliberate and logical: for the EPO to deal with property issues, it would have to have at its disposal either a self-contained body of property law, or a complete set of conflict-oflaws rules (which would be significantly more complex than the one-liner that deals with

\footnotetext{
${ }^{49} \mathrm{G} 1 / 13$, para 7 .

${ }^{50} \mathrm{G} 1 / 13$, para 9 .
} 
infringement) and the expertise to apply the selected national law as necessary. The choice to keep substantive property law outside the scope of the EPC and the choice to leave the jurisdiction over entitlement disputes to the courts of the contracting states are clearly interconnected: the combination of these two elements was meant to avoid having to write a unified body of property law and to ensure that the divisions of the EPO would not have to apply national property law.

Nevertheless, in view of the proprietary nature of party status in proceedings before the EPO, there are situations where the EPO is forced to make determinations about matters of property law, like it has to make determinations about the capacity and existence of persons acting as parties in proceedings before $i^{51}$. The general rule for issues of property law under the EPC states that the respective national law of each of the contracting states applies to the European patent or patent application (the "bundle" analogy) ${ }^{52}$. This rule is too impractical to serve the purpose of allowing the EPO to determine, at any given time, who the legitimate parties to the proceedings before it are. Hence, this goal is instead accomplished under the EPC by a presumption of entitlement in favor of the person applying for a patent ${ }^{53}$, and a simplified assessment of any purported transfers of that entitlement ${ }^{54}$.

\subsection{Presumption of Entitlement}

The presumption of entitlement of the applicant was introduced because the drafters of the EPC wanted to avoid a situation where the EPO would have to actively verify the grounds of the applicant's entitlement. Thus, although the form for applying for a European patent requires the applicant to indicate how he has obtained the right to the European patent ${ }^{55}$, the stated entitlement cannot be questioned by the EPO.

If a dispute about the entitlement to the right to the European patent arises between the applicant and a third party while proceedings before the EPO are pending, a court of one of the contracting states has to decide the issue before the EPO will lift the presumption in favor of the applicant. The international jurisdiction over entitlement claims against the applicant for a European patent

\footnotetext{
${ }^{51}$ Visser 2016, p. 150.

52 Art. 2(2) and art. 74 EPC. Note that this rule does not explicitly exclude the selected state's conflict-of-laws provisions, implying that a renvoi might be possible.

${ }_{53}$ Art. 60(3) EPC.

${ }^{54}$ Art. 72 EPC; Rule 22 EPC.

${ }^{55}$ Art. 81 EPC.
} 
is governed by a dedicated protocol to the $\mathrm{EPC}^{56}$. The protocol takes precedence over other agreements on jurisdiction between contracting states, including (for EU member states) the Brussels I Regulation.

The national courts apply a mix of the scarce substantive law from the $\mathrm{EPC}^{57}$, national law designated by the relevant conflict-of-laws rule in the EPC if the inventor is an employee ${ }^{58}$, and national law designated by the relevant conflict-of-laws rules in the forum's own private international law otherwise. A number of provisions in the EPC tell the EPO how to deal with judgments rendered according to the protocol, such that the outcome of the judicial process is duly recognized ${ }^{59}$.

\section{$\underline{\text { 5.3. Assessment of Transfers }}$}

Successions in title that occur after the filing of the European patent application, i.e. transfers from the original applicant who was presumed to be entitled, to a third party, may also be a source of contention. The EPC explicitly specifies which criteria a transfer of a European patent application has to meet in order to be opposable to the EPO. Thus a minimal body of property law exists in the EPC, and for these aspects the EPC excludes the application of national law ${ }^{60}$. As soon as the transfer is opposable to the EPO, the transferee is recorded in the European Patent Register as the new applicant and the EPO has to continue the grant proceedings with the registered transferee.

This system raises the question of the extent to which provisions such as art. $72 \mathrm{EPC}-$ which only states that an assignment in writing bearing the signatures of the parties is required for a transfer of a European patent application - can override the national law that would otherwise apply.

One could argue that since the material conditions of validity and the transfer of property are not harmonized by the EPC, they remain in the realm of national law in accordance with the conflict-of-laws rule of art. 74 EPC. In this hypothesis, art. 72 EPC only limits the conditions that must be checked by the EPO, but not the substantive conditions that must be fulfilled by the

\footnotetext{
${ }^{56}$ Protocol on Jurisdiction and the Recognition of Decisions in respect of the Right to the Grant of a European Patent (Protocol on Recognition), which is part of the EPC by virtue of art. 164(1) EPC.

${ }^{57}$ In particular, art. 60(1), first sentence, EPC.

${ }^{58}$ In particular, art. 60(2), second sentence, EPC.

${ }^{59}$ Art. 61 EPC; Rules 16-18 EPC.

${ }^{60}$ Art. 71-73 EPC; Rules 22-23 EPC. Rule 85 EPC extends the scope of Rule 22 to transfers of European patents during the opposition period or during opposition proceedings.
} 
transfer ${ }^{61}$. However, this approach has as a consequence that a single transfer instrument may be considered valid in some contracting states, and invalid in others, as each national court assesses the transfer in the light of its own national law (or in the light of the applicable national law designated by its conflict-of-laws rules ${ }^{62}$ ). Moreover, this approach could lead to a situation where the procedural prerogatives of the applicant vis-à-vis the EPO (e.g., the right to comment on the search and examination reports ${ }^{63}$, to amend the application ${ }^{64}$, and to approve the text intended for grant ${ }^{65}$ ) become separated from the substantive right to the patent and the resulting right to exclude others from practicing the patented invention.

An alternative approach consists of interpreting art. $72 \mathrm{EPC}$ as a provision that harmonizes the requirements for transfer by supplanting national provisions, i.e. as a prohibition for national law to impose additional conditions on the validity and effectiveness of a transfer agreement that meets the requirements of art. $72 \mathrm{EPC}^{66}$. This position has recently been endorsed by the Board of Appeal in T 205/14, which stated that "Article 72 EPC 1973 constitutes harmonised law with respect to the formal requirements for a transfer of a validly filed European patent application and overrules as lex specialis national law which, in general, governs legal acts related to property interests in such applications" 67.

Nevertheless, T 205/14 does not dispose of the issue entirely. If art. 72 and 74 EPC are considered with due attention to the place these articles have within the overall system of the EPC, in particular their place in the chapter about the European patent application as an object of property, it can be argued that while art. 72 determines in a self-contained way the transferability and the manner of transferring the property right in the European patent application, it does not affect national contract law. There is case law of the Boards of Appeal of the EPC that states that only "evidence of a completed transfer" may be registered, and not a contract that only comprises an obligation to transfer ${ }^{68}$. These cases appear to imply that art. 72

\footnotetext{
${ }^{61}$ This appears to be the gist of the compromise that was reached during the drafting of this provision, cf. Arbeitsgrupe "Patente" 1962, p. 44. As far as I could find out, the bundle-based conflict-of-laws rule now laid down in art. $74 \mathrm{EPC}$ was not part of the draft Convention at that time.

${ }^{62}$ E.g., the rules on formal validity of contracts under the law designated by art. 11 Rome I Regulation.

${ }^{63}$ Art. 94(3) EPC.

${ }^{64}$ Art. 123(1) EPC.

${ }^{65}$ Art. 113(2) EPC; Rule 71(5) EPC.

${ }^{66}$ Visser 2016, p. 153; Almer 2013, pp. 393-394.

${ }^{67}$ TBoA 18 June 2015, T 205/14 (Ibandronate sodium, Form QQ/TEVA), 3.6.1, ECLI:EP:BA:2015:T020514.20150618.

${ }^{68}$ LBoA 24 January 2002, J 12/00 (Transfer in ownership/KOHNO ET AL),2 and 14, ECLI:EP:BA:2002:J001200.20020124, concerning a contract under US law, where the distinction between an agreement to assign and an assignment is made, see also Beck 2009; J 4/10, para 5.4, concerning a contract under Korean law.
} 
EPC establishes a tradition system for European patent applications, in which the agreement containing the obligation (Verpflichtungsgeschäft) and the agreement effecting the transfer (Verfügungsgeschäft) are distinguished from each other, and in which the EPC only harmonizes the latter. In such a system, the EPO can carry out the registration after verifying that the agreement effecting the transfer meets the requirements of the EPC, and need not concern itself with the underlying obligation. The obligation remains a matter for national law, as it is common ground that for the purpose of a conflict-of-laws analysis, "contracts which deal with intellectual property are, of course, just contracts" ${ }^{\circ 9}$.

But the analysis must be taken one step further. The question remains whether a valid transfer can be deemed to have taken place under art. 72 EPC if there is no underlying obligation or causa that is valid under national law, i.e. whether art. 72 EPC realizes a transfer at a level that is abstracted from the underlying title (abstract system), or whether the avoidance of the causa automatically renders the transfer void (causal system). This question arises in particular if the validity of a transfer is challenged after its registration by the EPO. It turns out that only an abstract system is compatible with the contracting states' intent to avoid letting the EPO assess the validity of agreements under national law.

Assuming the causal interpretation, the EPO could be asked to undo the registration of a transfer that meets the requirements of art. 72 EPC, upon production of evidence that the underlying causa is invalid under the applicable national law: this would force the EPO to make a determination of the applicable national law and assess the validity of the causa under said national law, a determination for which it is ill equipped. In the abstract interpretation, on the other hand, a registered transfer can only be undone by the EPO if the adversely affected party proves that the transfer was registered despite the fact that the instrument submitted to effect the transfer did not meet the requirements of art. 72 EPC.

The Legal Board of Appeal has had an opportunity to discuss some of the distinctions outlined above in case $\mathrm{J} 4 / 10^{70}$. The case concerns an international patent application, filed by Korea Microbiological Laboratories Inc. (hereinafter: Komipharm), for which a notification of a change in the identity of the applicant was filed during the international phase, leading to the addition of Messrs. Lee and Yang as applicants for all designated states ${ }^{71}$. The European phase

\footnotetext{
${ }^{69}$ Briggs 2013, p. 311.

${ }^{70}$ LBoA 15 March 2012, J 4/10 (Registration as co-applicant/KOMIPHARM), ECLI:EP:BA:2012:J000410.20120315.

${ }^{71}$ Procedure according to Rule 92bis.1 PCT.
} 
was subsequently entered, whereby only the original applicant was registered. After the EPO's communication of its intention to grant a European patent, Lee asked the EPO to add his name to the application as an applicant, in accordance with the change that had been notified during the international phase. The EPO initially granted this request, without requiring further evidence. Komipharm immediately replied that there had never been a transfer of rights to Lee and Yang, and requested that the registration be undone. Upon submission by Lee of a Korean document and its translation as evidence of the transfer, the legal division rejected Komipharm's request ${ }^{72}$. Komipharm then lodged an appeal against this rejection.

In the appeal proceedings, the parties referred to a proceeding that had meanwhile been started before the Central District Court of Seoul, in which the validity of the contract submitted by Lee was at issue. The Legal Board of Appeal did not find convincing evidence of the alleged transfer in the ruling of the Seoul Court, and issued a provisional opinion in which it considered Komipharm's appeal allowable. However, between the provisional opinion and the oral proceedings, the decision of the District Court was set aside by the Civil High Court of Seoul, which ruled that the contract at issue was void.

In its final decision, the Legal Board of Appeal refused to uphold the purported transfer of rights to Lee on two independent grounds. Firstly, it held that the agreement produced by Lee did not comprise a transfer, but "at most constitutes a legal obligation to transfer rights concerning the PCT application" "73. This conclusion is presented by the Board without any indication of the law according to which the agreement was interpreted (the agreement itself includes an express choice for South Korean law, but the Board does not indicate if and on what basis this choice was respected, nor where it would have obtained the necessary information about the content of South Korean law). It may thus be assumed that the agreement was only assessed by the Board to verify if it satisfied the autonomous requirements of art. $72 \mathrm{EPC}$, in the interpretation that this article institutes a tradition system, rather than a consensual system. Under that assumption, there was no need for the Board to assess the obligations that may have been embodied in the document, and that would have been governed by national law.

\footnotetext{
${ }^{72}$ As the submitted document did not bear signatures, the Legal Division requested Lee to provide additional documentary evidence, bearing at least the signature of the assignor (this deviates from art. $72 \mathrm{EPC}$, but follows Section E XIII-1 of the Guidelines, as valid at the time). Lee indicated that the submitted document was provided with seals having the same effect as signatures under Korean law. The Legal Division accepted this explanation, applying the rule locus regit actum without any legal basis.

${ }^{73} \mathrm{~J}$ 4/10, para 5.4 .
} 
Secondly, the Board of Appeal held that the agreement could no longer serve as evidence in favor of Lee, due to its being declared null and void by the High Court ${ }^{74}$. From the point of view of private international law, it is interesting to see that the Board recognized the decision of the Seoul High Court, and the resulting nullity of the contract, de plano. However, this part of the decision does not add any weight to either an "abstract" or a "causal" interpretation of art. 72 EPC.

As an apparent consequence of the Komipharm case, the section about the registration of transfers in the Guidelines for Examination at the EPO was amended ${ }^{75}$. As of the November 2014 edition, the Guidelines state that "art. 72 EPC is an autonomous provision which exclusively governs the formal requirements of such transfers." They further specified that if the transfer was challenged by the originally registered applicant, the legal divisions would have to restore the status quo until the valid legal situation had been proven. The required proof of the valid legal situation could take the form of a judgment of a national court. The latter instruction was subsequently removed from the Guidelines as a result of more recent case law ${ }^{76}$.

\section{$\underline{\text { 5.4. Universal Succession }}$}

As mentioned above, the interest in the application or patent, which is being pursued by an applicant or proprietor in grant or opposition proceedings before the EPO, is an interest in property, and party status thus follows the property right ${ }^{77}$. While this reasoning cannot be directly applied to the party status of an opponent in opposition proceedings, because there is no underlying property right associated with it, the treatment of heirs of a deceased opponent as its successors in the proceedings indicates that even opponent status has a proprietary nature according to the Boards of Appeal ${ }^{78}$. Having recognized this proprietary nature of opponent status, the Boards of Appeal have generalized the rule to successions on other grounds. While the relevant case law deals predominantly with transfers of opponent status, these successions on other grounds also apply to patent applications, as distinct from the individual transfers envisioned by art. $72 \mathrm{EPC}^{79}$.

\footnotetext{
${ }^{74} \mathrm{~J}$ 4/10, para 5.8-5.9.

${ }^{75}$ EPO 2014, E-XII 3.

${ }^{76}$ EPO 2016, E-XIII 3, with reference to LBoA 15 June 2015, J 16/14 (Transfer and reversal of transfer...), ECLI:EP:BA:2015:J001614.20150615.

${ }^{77}$ EPO 2013, p. 535.

${ }^{78}$ Rule 84(2) EPC.

${ }^{79} \mathrm{~T} 15 / 01$, para 9.
} 
In $\mathrm{T} 74 / 00$, the appellant-opponent concerned had died, leaving her two children as apparent heirs ${ }^{80}$. The Board held that it was "beyond doubt that the relevant national law of succession [was] that of Japan", referring to the fact that all the relevant persons were residing in Japan. The fact that legal heirs could continue the appeal proceedings started by their predecessor was a matter of autonomous procedural law of the EPC, while the question whether the persons presenting themselves as such were the legal heirs of the deceased party was deemed to be a matter of national law. The applicable conflict-of-laws rule was not mentioned explicitly.

Outside the cases of a death of an opponent, the Boards of Appeal have recognized the transfer of opponent status as an accessory of the assets of the business division in whose interest the opposition was lodged, the transfer of which is governed by national law ${ }^{81}$, and as a result of a universal succession ${ }^{82}$. While the existence of a valid transfer of "all the assets of a business division" can be assessed on the basis of any applicable national law, the concept of "universal succession" is not present in all legal systems. Thus, in T 15/01, the Board of Appeal indicated that autonomous EPC law would have to be used to arrive at a correct assessment of successions ${ }^{83}$ : "While it is true that the status of a legal person as such has to be determined by the applicable national law, the issue whether a non-existing person can remain a party to the proceedings before the EPO is to be determined autonomously by the procedural law of the EPC.”

Subsequently, in T 2357/12, the Board held that "universal succession" is a concept of procedural law under the EPC that is to be construed autonomously by the EPO, independent from national law ${ }^{84}$. That being said, the Board enunciated a typology of "successions", with an indication as to whether each type would qualify as "universal successions" under the procedural law of the EPC. The typology hinges on criteria such as the continued existence of the predecessor-in-title, whether the succession occurs by law, and whether all relevant assets remain united after the transition.

\footnotetext{
80 TBoA 15 March 2005, T 74/00 (Scanning Confocal Endoscope/OPTISCAN), ECLI:EP:BA:2005:T007400.20050315.

${ }^{81}$ EBoA 24 April 1989, G 4/88 (Transfer of opposition), ECLI:EP:BA:1989:G000488.19890424.

${ }^{82}$ Ibidem, at 4.

${ }^{83} \mathrm{~T} 15 / 01,9$.

${ }^{84}$ TBoA 28 November 2013, T 2357/12 (Universal Succession), para 7 and 10-12, ECLI:EP:BA:2013:T235712.20131128.
} 


\section{$\underline{\text { 5.5. Analysis }}$}

The proprietary nature of applicant status has a firm basis in the EPC, and its extension to opponent status appears quite natural. While some issues of property law are harmonized by the $\mathrm{EPC}$, the issues that are left to national law are normally to be resolved by national courts. However, we see the EPO moving away from a self-contained conception of the harmonized rules, and towards a mixed conception in which it assumes a responsibility to apply national law in order to answer preliminary questions before turning to the harmonized rules.

In view of the conclusions presented above on the abstract nature of the transfer system instituted by the EPC for European patent applications, a temporary suspension of the application of art. 72 EPC until a national court has had it say about the valid legal situation, as previously required by the Guidelines, is not justified. It goes against the clear meaning and intent of art. 72 EPC and the interpretation subsequently given in T 205/14, and relies on judgments of national courts for the recognition of which there is no legal basis in the EPC. If a purported transfer is tainted by a defect arising under national law, but the presented evidence meets the requirements of art. $72 \mathrm{EPC}$, it is neither the place nor the competence of the EPO to refuse (or undo) the registration of that transfer ${ }^{85}$. As is normal in abstract systems, the injured party should go to the competent national court to obtain an order forcing the unlawful recipient of the patent application to transfer it back to the original holder in accordance with art. 72 $\mathrm{EPC}^{86}$.

In the domain of universal successions, the abstraction principle does not come into play and applying a mix of EPC law and national law is justified. In this context, the EPO's case law makes a sensible distinction between the procedural rules regarding the requirements to have locus standi, which are governed by EPC law, and the questions that must be asked of a person to find out whether it meets these requirements, which are a matter of national law. Thus, the question whether someone qualifies as a deceased party's heir cannot be answered without reference to national law, and neither can the inquiries that lead to the qualification of a succession as a "universal succession" in the sense of T 2357/12.

\footnotetext{
${ }^{85} \mathrm{~J} 16 / 14$, paras 2.3 .1 and 2.4

${ }^{86}$ Bartels 2008, 60.
} 


\section{Entitlement to Priority}

\subsection{The Issues at Stake}

The Paris Convention establishes a union for the protection of industrial property ${ }^{87}$. A person who applies for a patent in one country of the union, or his successor in title, enjoys a right of priority in all other countries of the union for twelve months. While obtaining a filing date for a priority application in a first country according to the laws of that first country is a factual prerequisite for a priority right to come into existence, the legal effects of the priority right are created by the laws of the country in which the subsequent application is filed and where the priority right is invoked, either by virtue of the direct effect of the Paris Convention or by its implementation in national law. According to the prevailing view, the Paris Convention does not have direct effect in the context of European patent applications, but a priority system with the same effects is established by the self-contained provisions of the $\mathrm{EPC}^{88}$.

The loss of a priority right can be fatal for a patent, because prior art having a publication date between the claimed date of priority and the actual filing date of the patent application will be taken into account in the determination of the novelty and inventive step of the claimed invention, if the claimed priority right is not valid. A correct assessment of the validity of a priority right, including a correct assessment of the holder of that right, is therefore crucial. In recent years, numerous European patents have been opposed on the ground of an alleged lack of entitlement of the applicant to the priority right. One recurring fact pattern in these cases consists of the following elements ${ }^{89}$ : (1) the priority application was filed as a patent application naming the inventor-employee as the applicant, though the employer was entitled to the right to the patent ${ }^{90}$; (2) the subsequent application was filed as an international or European patent application naming the employer as the applicant; (3) the entitlement of the European applicant to the priority right is questioned by an opponent after grant. In cases of this type, the fate of the patent may depend on whether the applicant of the European patent application (i.e., the employer) can prove that he is the successor in title of the applicant of the priority application (i.e., the inventor-employee) - it is clear that the choice of the applicable law can have an impact

\footnotetext{
${ }^{87}$ Art. 1 Paris Convention for the Protection of Industrial Property of 20 March 1883, as last amended on 28 September 1979, http://www.wipo.int/treaties/en/ip/paris/.

${ }^{88}$ See Visser 2014, p. 7; Baque 2008, p. 147; both referring to J 15/80.

${ }^{89}$ As noted by Bremi 2010b. Recently, the same objection also appeared in third-party observations during the examination stage, e.g. European patent application no. 05777317.8 .

90 This was in practice the only way of filing a patent application in the USA prior to 16 September 2012, when the Leahy-Smith America Invents Act (AIA) introduced the possibility for an assignee of the inventor to be the initial applicant, and thus the initial beneficiary of the priority right; 35 USC 118.
} 
on whether such a proof will be successful, especially when the applicant relies on an implicit assignment or a transfer by operation of law.

\subsection{Characterizing the Issues}

Considering the right to priority as an object of property, questions arise as to which law governs the transferability of the priority right, and which law governs the actual transfer. Generally speaking, the candidate legal systems are those connected to any underlying agreement (lex contractus, typically determined by reference to connecting factors such as an express choice of law, the residence of the assignor or the place were an employee is habitually employed), the state where the original application was filed (i.e., where the priority right comes into existence, lex originis, considering the priority right as an accessory of the first application), and the state where the subsequent application was filed (i.e., where the priority right is claimed and protection is sought, lex loci protectionis, considering the priority right as an accessory of the subsequent application). When a lex loci protectionis rule is applied in proceedings before the EPO, there is of course no single "state for which protection is sought", so the entire combined territory of the Contracting States of the EPC becomes a single, virtual law district having "EPC law" as its legal system.

Issues of transferability of intellectual property rights are generally left to the lex loci protectionis $^{91}$. It is not disputed that art. 87(1) EPC establishes that the priority right is transferable, and no recourse to any national law is taken on this point ${ }^{92}$. Moreover, the prevailing view is that under art. 87(1) EPC, the priority right is transferable independently of the priority application which brings it into being ${ }^{93}$.

\footnotetext{
${ }^{91}$ Ulmer 1978, p. 101; Metzger 2005, p. 63; Van Engelen 2007, no. 333; European Max Planck Group on Conflict of Laws in Intellectual Property 2013, Article 3:301.

92 T 62/05; T 205/14.

${ }^{93}$ A different conclusion was reached in Opp. Div. 31 May 2013, patent application no. 09000013.4, at 2.1.3 (appeal pending), discussed below.
} 
However, neither the Paris Convention nor the EPC specifies the requirements a transfer of the priority right should fulfill, and it is not immediately clear which conflict-of-laws rules should be used to arrive at the law applicable to this question. While this matter has received attention from patent practitioners since $2009^{94}$, i.e. after the judgment in Edwards Lifesciences AGv Cook Biotech Inc. ${ }^{95}$, and once again after T $205 / 14^{96}$, the available academic literature is scarce $^{97}$. 6.3. Case Law of the Boards of Appeal

The case law of the Boards of Appeal in the domain of transfers of priority rights - at least until 2010 - has been criticized as being contradictory ${ }^{98}$. In this section, various decisions of the Boards of Appeal on this topic are discussed, with a view to identifying the different conflict-oflaws rules that have (often implicitly) been applied.

\section{$\underline{\text { 6.3.1. Early Cases }}$}

In J 19/87, the Legal Board of Appeal applied English law to determine whether a (retro)cession of a priority right had taken place ${ }^{99}$. To that end, the applicant-appellant had provided an opinion of an expert at English law, at the request of the rapporteur of the Board ${ }^{100}$. In this case, the priority application was an English patent application, and the transfer was agreed between parties residing in England and Wales. It is not clear from the record which of these elements had led the Rapporteur to the conclusion that the transfer of the priority right had to assessed in the light of English law, as all the relevant connecting factors pointed towards English law.

In T 1008/96, the Board of Appeal stated that national law had to be applied to assess the alleged transfer or the priority right, without however specifying how the applicable national law should be identified ${ }^{101}$. In this case, the alleged priority applications were Italian patent applications and the involved parties resided in Italy. As all the connecting factors pointed towards Italian law, this was certainly the law with which the case had the closest connection. However, there is no clear indication in the decision that any specific rule from Italian law was ever applied to the case. It rather seems as though the Board of Appeal never got beyond the point of judging the

\footnotetext{
${ }^{94}$ For example: Bremi 2010a; Bremi 2010b; Schweizer 2011; Tronson 2011; Korenberg 2011.

95 High Court of Justice (UK), 12 June 2009, no. 95, www.bailii.org.

96 Teschemacher 2016; Ho and Molnia 2016.

${ }^{97}$ Although the issue is addressed in Ulmer 1978, p. 56 (no. 85) and p. 97 (no. 152).

${ }^{98}$ Bremi 2010a.

${ }^{99}$ LBoA 21 March 1988, J 19/87 (Assignee), ECLI:EP:BA:1988:J001987.19880321.

100 The expert reached the conclusion that the assignee had obtained equitable title in the priority right, and that this was enough to allow him to claim the priority. The Board of Appeal followed that analysis.

101 TBoA 25 June 2003, T 1008/96, para 3.3, ECLI:EP:BA:2003:T100896.20030625.
} 
probative value of the elements invoked to support the existence of the alleged transfer, a judgment they could make on the basis of the evidentiary rules of the lex fori.

The only pattern that emerges from these cases, is that if both parties to the purported transfer are in the same country and the priority application is a patent application for that same country, the law of that country governs the transfer of the priority right. This is hardly general enough to be called a conflict-of-laws rule, although it has been applied as one ${ }^{102}$.

\subsubsection{T 62/05: A New Approach?}

In T 62/05, the Technical Board of Appeal was confronted with a context that deviated from the pattern of J 19/87 and T 1008/96: the intended priority application was a Japanese patent application and the parties involved in the (alleged) transfer of the priority right resided in different countries (Japan and the USA). The connecting factors thus pointed in different directions. Instead of honoring the statement in T 1008/96 that "national law" had to be applied in this context, the Board stated that the EPC contains no rules about the formal requirements that a transfer of a priority right must meet in order to be valid for the purpose of art. 87(1) EPC, but that it appeared reasonable to apply the same "standard of proof" as required for the transfer of a transfer of a patent application ${ }^{103}$. On that basis, art. 72 EPC was applied to the alleged transfer of priority, leading to the conclusion that the validity requirements were not met.

However, as indicated in section 5.3 above, art. 72 EPC pertains to more than a standard of proof; it provides the formal requirements for the validity of a transfer of a patent application in an abstract system. The application of art. 72 EPC to priority rights in T 62/05 may be interpreted in the same way. Thus, from a conflict-of-laws point of view, T 62/05 may be said to present an application of the lex loci protectionis to the question of validity of the transfer of the priority right, whereby the applicable substantive provision of EPC law was found by the Board to be the newly enunciated rule that art. 72 EPC should be applied by analogy. In so doing, the Board implicitly suggested that the priority right under the EPC is also subject to an abstract system of transfer, independent of any underlying obligation.

In a number of subsequent cases, a transfer of a priority right was recognized on the basis of a transfer agreement that met the requirements of art. $72 \mathrm{EPC}$, as required by the rule from $\mathrm{T}$ $62 / 05$, but it is not clear whether that aspect was decisive; the result would have been the same if

\footnotetext{
102 Opp. Div. 24 September 2014, European patent application no. EP 97905876.

103 TBoA 14 November 2006, T 62/05, para 3.7-3.8, ECLI:EP:BA:2006:T006205.20061114.
} 
the lex originis or the law of the state with the closest connection had been applied ${ }^{104}$. Hence, these cases provide no hint as to whether the Boards of Appeal concerned had abandoned the application the law of the state with the closest connection in view of $\mathrm{T} 62 / 05$.

\subsubsection{After T 62/05: The Conflict Is Made Explicit}

As illustrated by the following examples, the first-instance divisions chose not to follow the rule of $\mathrm{T} 62 / 05$ systematically.

The MedImmune case ${ }^{105}$, follows the pattern outlined in section 6.1. In that case, the opposition division decided that the law applicable to the question of the validity of a purported transfer of the priority right was the lex originis, i.c. US law. According to the opposition division, there was no evidence of such a transfer - a conclusion that could be reached without any concrete application of US law - such that the applicant was not entitled to claim the priority right. In appeal, the proprietor-appellant requests that the transfer be assessed on the basis of the law - in particular, the law of the state of Maryland - but that special consideration be given to the transfer of the equitable title, which occurs as a matter of law between an employee and his employer.

A remarkably extensive discussion of the same question can be found in the decision of the opposition division in the Innovative Sonic case ${ }^{106}$. The opposition division explicitly recognized the fact that the applicable law must first be identified, in order to determine the relevant validity requirements for the transfer of the priority right. The opposition division first pointed out that it considered that the rule of T 62/05 only applies to the standard of proof, and not to the identification of the law applicable to the validity of the transfer. In the absence of explicit conflict-of-laws provisions in the EPC, the opposition division attempted to identify general principles of procedural law common to the contracting states. This led to the identification of the separate issues of transferability and validity of the transfer, to the choice of the lex loci protectionis as governing the transferability of the priority right, and to a choice of law in accordance with the principles of the Rome I Regulation for the validity of the purported transfers. Unfortunately, the opposition division incorrectly interpreted the concept of the lex loci protectionis when applied to priority applications, as the law of the country where the

104 TBoA 18 September 2007, T 493/06 (Phagemid/KREBSFORSCHUNGSZENTRUM), ECLI:EP:BA:2007:T049306.20070918; TBoA 26 September 2008, T 382/07 (Etheric oils/D \& W TRADING), ECLI:EP:BA:2008:T038207.20080926;

${ }^{105}$ Opp. Div. 23 April 2013, concerning EP 99967 460.9, presently pending in appeal as T 2161/13.

106 Opp. Div. 31 May 2013, concerning EP 09000 013.4, presently pending in appeal as T 1763/13. 
priority application was filed, and concluded that under US law, a priority right cannot be transferred independently of the patent application. It then analyzed the purported subsequent transfers of the priority application under their respective lex contractus, and concluded that the purported chain of title was not adequately proven. In a further case between the same parties, the opposition division refined its reasoning by exploring whether the law that governs the transferability of the priority right should also govern the validity of a transfer; finding no common ground in the practice of the Contracting States, the opposition division applied the principle of the favor negotii to allow the validity of the transfer to be governed by the law that is most favorable to a finding of validity - however, US law remained the only candidate and the outcome of the case remained unchanged ${ }^{107}$. In yet another case between the same parties, the question was raised whether the retroactive effect of a transfer of a priority right, as recognized under the national law designated by the relevant conflict-of-laws provision, should also be recognized by the EPO. The opposition division held - and the Technical Board of Appeal confirmed - that such a retroactive effect could not be relied on to meet the requirement of the EPC that the priority right must have been transferred before the filing of the European patent application ${ }^{108}$. This lex fori based approach to retroactivity is in marked contrast to the approach taken by the Enlarged Board of Appeal in G 1/13 (see section 4.4).

In case T 205/14, a Board of Appeal provided the most comprehensive conflict-of-laws analysis to date. In this decision, the rule of $\mathrm{T} 62 / 05$ is dismissed as merely being concerned with imposing a standard of proof for showing the existence of a transfer, which is incompatible with the principle of unfettered evaluation of evidence that prevails in EPC law. Turning to the substance, the Board of T 205/14 states that "neither the systematic context ... nor the preparatory work to Article 72 EPC 1973, which is silent with respect to the question of transfer of the right of priority, leave room for applying Article 72 EPC 1973 in a way which goes beyond its clear wording" 109 .

However, while any type of evidence may be adduced to prove a transfer of a priority right, the Board's assessment of that evidence would need to be made by reference to defined formal and material requirements - the silence of the EPC is therefore not taken as "a conscious choice of the legislator that the transfer of a right of priority is free of requirements as to form and

\footnotetext{
107 Opp. Div. 30 July 2013, concerning EP 08009 849.4.

108 Opp. Div. 14 March 2014, concerning EP 07014 824.2; TBoA 9 February 2017, T 1201/14 (Transfer of right of priority), ECLI:EP:BA:2017:T120114.20170209, para. 3.2.1.

109 T 205/14, para 3.6.1.
} 
content", but necessitates a recourse to national law ${ }^{110}$. The Board recognizes that the EPC is silent on the choice of law to be made with respect to the assessment of the validity of a transfer of rights of priority, and then puts forward its considerations in favor of "the law applicable to the legal relationship between the transferor and the transferee of the right of priority". These considerations include the fact that legal certainty and predictability require that the transfer of a priority right be governed by a legal system that the transferor and the transferee are familiar with; the independence of the right of priority from the fate of the priority application, indicating that the law of the state of filing of the first application has no bearing on the question of a valid transfer; and the legislator's understanding, expressed in the conflict-of-laws rule laid down in art. 60(1) EPC for the determination of entitlement to the invention in an employment relationship (see above, section 5.2), that obligations of the employer and the employee in relation to a transfer of an intellectual property right shall be governed by the law of the state to which the employment relationship is most closely connected.

The choice of "the law applicable to the legal relationship between the transferor and the transferee of the right of priority" (lex contractus) to govern the obligations of the transferor complies with the general principles on the law applicable to obligations (see also section 2.1). However, one might argue that the Board has only kicked the can further down the road, in that it remains to be decided how to identify the lex contractus. One might glean inspiration from art. 60(1) EPC in the case of an employment relationship, but that does not deal with the situation of contract researchers, consultants, officers of legal persons, licensees that invent improvements to a licensed invention, and all the other categories of inventors that may have a legal relationship with another party pertaining to their inventive activity, with different connecting factors pointing to different national laws.

\subsection{Analysis}

\subsubsection{A Matter of Distinctions}

Most of the cases discussed above recognize the importance of distinguishing between the transferability and the transfer of a priority right. However, they all stop short of disentangling the actual transfer from the obligation to transfer. T 205/14 even expressly states that the distinction between an obligation to assign a right and the assignment itself has no bearing on the transfer of a right to priority if, according to the applicable law, the right is transferred by

${ }^{110}$ T 205/14, para 3.6.2-3.6.3. 
operation of law or if an assignment does not require specific formalities and thus can be implied from the circumstances ${ }^{111}$. This statement fallaciously skips a step in the conflict-of-laws analysis, as one can only conclude that a transfer is "by operation of law" or "without formalities" after determining the law applicable to the transfer.

In fact, except in the case of a universal succession, the transfer of the priority right will typically be based on an underlying obligation of the transferor. Even if the chosen national law provides for an "automatic assignment" of the right to an invention in certain circumstances, for example in the case of employee inventions, it should be borne in mind that the priority right normally comes into existence after the "automatic assignment" has run its course: the priority right is a new right that formally vests in the applicant named in the priority application, notwithstanding the fact that the substantive right to the invention no longer belongs to him. The same holds mutatis mutandis if the national law causes the initial right to the invention to vest in someone other than the inventor, in which case there is no assignment of this right at all ${ }^{112}$. If in such cases an applicant (e.g. the inventor ${ }^{113}$ ) is allowed by the truly entitled party to file a patent application in his own name, it is clear that he acts on behalf of the truly entitled party, and assumes an obligation to transfer the rights so obtained to the latter. Of course, in a purely consensual system, the transfer will take place as soon as the obligation comes into existence ${ }^{114}$, and a similar effect can be obtained in common law systems by applying the maxim that "Equity regards as done that which ought to be done" 115 , but that doesn't take away the fact that an obligation underlies the transfer.

It may be noted that certain legal systems provide for an automatic transfer of rights related to an invention after the filing of the priority application ${ }^{116}$. Although the analysis provided above does not apply to these systems, the existence of these systems does not remove the need to include the distinction between an obligation to transfer and a transfer in the general conflict-oflaws analysis.

While it makes sense to assess the obligation by reference to the lex contractus, the lex loci protectionis appears to be the theoretically soundest choice to govern the actual transfer. If the

\footnotetext{
111 T 205/14, para 3.8.1.

112 E.g., in the Netherlands, art. 12 (1)-(3) Patent Act 1995 list situations where the right to the patent belongs $a b$ initio to the employer or supervisor of the inventor.

${ }^{113}$ In particular, because he is the only person who has the procedural standing to do so, as was the case with inventors under pre-AIA US law.

114 Van Erp and Akkermans 2012, p. 654.

115 Worthington 2006, p. 264.

${ }^{116}$ Cf. for Germany: Ho and Molnia 2016, p. 20.
} 
lex loci protectionis determines under what conditions a patent right is granted, it also determines to whom it is granted and who is entitled to the right ${ }^{117}$; this reasoning may easily be extended to the entitlement to the priority right that may be invoked before the authorities of the locus protectionis. Moreover, this treatment of priority rights is compatible with the view that the EPC uses its own "self-contained" set of rules concerning priority, thus providing a separate lex loci protectionis ${ }^{118}$.

T 205/14 takes a radically different approach, assessing the validity of the transfer of the priority right by reference to the law that governs the underlying legal relationship and its resulting obligations. It thus presumes a causal system adhering to the Einheitstheorie, which is in fact the only system that is fully compatible with the lack of substantive provisions in the EPC and requires no judicial creativity on the substantive side - although it requires a great deal of judicial creativity on the side of the conflict-of-laws provisions.

\subsubsection{The Case for EPC Law}

Even if the approach of T 205/14 provides a seemingly appropriate way of dealing with the lack of substantive provisions in the EPC, it draws the EPO into a responsibility for dealing with national law which the legislator never intended it to take on, and without the benefit of the presumption of art. 60 EPC and the Protocol on Recognition. Moreover, applying any other law than the lex loci protectionis to a transfer of priority rights presents a number of difficulties.

A first issue is that legislators typically do not provide legal provisions covering situations that do not occur in their own legal system, just in case a foreign jurisdiction decides that their laws apply to a situation occurring in that foreign country. Thus, in pre-AIA US patent law, which presumably still applies to a number of transfers of priority rights of which the validity remains to be determined, a patent application is always made by or on behalf of the inventor and the inventor may invoke the priority right arising out of any earlier application made by him or his assigns ${ }^{119}$; it is clear that such a system has no need for any transferability of the priority right, and as a result there are no legal provisions pertaining to the validity requirements for such a transfer. Hence, even if an obligation between an employee and his employer is governed by the

\footnotetext{
${ }^{117}$ Fawcett and Torremans 2011, p. 730, at 13.116.

118 The same conclusion has been reached with respect to exhibition priority in case $\mathrm{T} 382 / 07$, where it was held that the question whether a right to such a priority exists must be answered in accordance with the lex loci protectionis, which, in the case of a European patent application or a European patent, meant the EPC itself (T 382/07, para 8.3). 11935 USC 119 (pre-AIA).
} 
law of a US state, pre-AIA US patent law would offer no help in determining whether a valid transfer of a priority right has taken place.

A second issue is that the law governing a given legal relationship and the substantive patent law may be situated at different levels in a multi-level legal system and thus fundamentally unrelated. Apart from being geographically linked to the same sovereign country, the law of any given US state that governs a legal relationship has as little to do with federal US patent law as it does with EPC law.

These first two issues may be resolved by avoiding the trap of trying to look in the designated national law for a rule pertaining to the transfer of priority rights, or even patent applications, which the foreign legislator would only have intended to apply to rights that can be invoked before its patent authorities. The priority right is an intangible object of property, so the most appropriate substantive rule to be applied may well be the rule pertaining to the transfer of intangibles in general.

A third issue is that national systems of property law may make distinctions that cannot easily be accommodated under EPC law. The distinction made under the common law between "legal title" and "equitable title" is such a distinction. If it is determined under US law that an employer has obtained "equitable title" but not "legal title" to a priority right, would that be enough for him to rely on the transfer before the $\mathrm{EPO}^{120}$ ? A substantively similar question arises under civil law systems when a successor attempts to rely on a transfer of economic ownership of the priority right, separate from the legal title ${ }^{121}$

A closely related issue arises in connection with the EPO's requirement that the transfer of a priority right must be completed before the filing date of the subsequent European patent application $^{122}$. The notion that national laws, which may well allow transfers of intangibles to have retroactive effect, govern the transfer of the priority right, is difficult to reconcile with such a strict time limit imposed by the lex fori. It is clear that this contradiction can be resolved by also applying autonomous EPC law to the transfer ${ }^{123}$.

In view of the above, a solution based on autonomous EPC law appears to be theoretically correct and called for. In the present state of the case law, the rule of $\mathrm{T} 62 / 05$ is the only

\footnotetext{
${ }^{120}$ Such a transfer of equitable title was given full effect in $\mathrm{J}$ 19/87.

${ }^{121}$ Such a transfer of economic ownership was denied effect in LBoA 14 April 2016, T 577/11 (Entitlement to priority), ECLI:EP:BA:2016:T057711.20160414, para 6.6.2.

${ }^{122}$ EPO 2016, A-III 6.1. This was at issue in T 1201/14 (see section 6.3.2).

${ }^{123}$ An alternative solution for this particular issue is to remove the time limit from EPC law. A convincing argument that there is no basis or need for such a requirement can be found in Haedicke and König 2016.
} 
candidate. Given its clear requirements, the rule of $\mathrm{T} 62 / 05$ provides as much legal certainty as the approach of $\mathrm{T} 205 / 14$. It abstracts the transfer of the priority right from the underlying obligation, avoiding any discussion of national law before the EPO. Nevertheless, it remains just a creative way of filling a gap, and it cannot be denied that art. 72 EPC was originally not intended to be applied to priority rights.

\section{Conclusions}

The EPC was designed to leave certain matters up to national law, which would be applied exclusively by national courts. This approach seems to work well for matters pertaining to infringement, where the European patent can be described as a "bundle of national patents". In other domains, the separation is less clear, and the EPO ends up having to apply national law despite the EPC's intent to avoid that.

Often, the "bundle" analogy turns out to be inadequate to resolve the conflict-of-laws issues that arise. In the absence of explicit conflict-of-laws rules in the EPC, the EPO has had to develop its own case law, and has resorted to applying national law according to its own insights. As the EPO does not follow a strict stare decisis doctrine, this approach does not guarantee legal certainty for the parties.

The consistent "party status" case law and the strong presumption in the EPC and the travaux préparatoires against any interpretation in which the EPO would have to apply national law indicate that silence of the EPC on a particular issue does not necessarily imply that national law must be applied. In particular, it would be desirable that the EPO give a preference to applying autonomous EPC law whenever the issues are so closely connected with EPO procedure that a uniform treatment is demanded. When there is a convincing reason for filling a gap in the EPC by applying national law, the problem should be carefully analyzed to identify any separate issues that may have to be characterized differently - national law may have to be applied for some issues, but not for others.

The reasoning of the Boards of Appeal in cases concerning the existence and capacity of (legal) persons shows an acute awareness of the fact that conflicts of laws occur, and that a conflict-oflaws rule must be applied. The actual selection of the applicable national law, where necessary, has turned out to be unproblematic, even though the determining connecting factors are rarely mentioned explicitly. Once identified, the relevant effects of the applicable national law are 
determined with help of the parties ${ }^{124}$. It is also noted that even though certain key concepts have been declared to be autonomous concepts of procedural law of the EPC, these concepts cannot be applied in practice without applying the appropriate national law.

In the field of property law, the situation is less satisfactory. The provisions of the EPC relating to the transfer of patent applications give rise to different possible interpretations in the light of the different property transfer systems of the contracting states, and if a role for national law is assumed, the lack of explicit conflict-of-laws rules cannot easily be remedied by resorting to general principles common to the contracting states. For the transfer of priority rights, the situation is even worse, as the EPO has recently shown a reluctance to adopt gap-filling substantive rules of EPC law, and chose to create its own conflict-of-laws framework instead. Indeed, the notion that the validity of a transfer of priority rights should be assessed by reference to "the relevant national law" is an old one ${ }^{125}$, and T 62/05 is an isolated case applying judgemade EPC law as the lex loci protectionis. As it is to be expected that the approach of T 205/14 will henceforth be followed by other Boards of Appeal, we have many refinements of the "law governing the legal relation" rule to look forward to, and we may hope that the Boards apply the rules of the designated national law in a manner that respects the specific nature of the right to be transferred.

The soon to be activated UPC will face many of the same issues as the EPO, as it will also have to deal with questions of party status, transfers of rights, and entitlement to priority. The UPC may even reassess challenges to the validity of European patents, which the EPO has dismissed. Unlike the EPO, the UPC will be bound by explicit conflict-of-laws rules, resulting either from EU legislation or from legislation of the EU member states. It will be interesting to see how the UPC will deal with issues of entitlement to priority - for which even the existing EU conflict-oflaws rules do not necessarily lead to a single solution - and how the interaction between the EPO and the UPC will play out.

\section{$\underline{\text { References }}$}

Almer K J (2013) Artikel 72 Rechtsgeschäftliche Übertragung. In: Stauder D, Luginbühl S (eds), Singer/Stauder: Europäisches Patentübereinkommen, Karl Heymanns Verlag, Köln, pp 393-394

\footnotetext{
${ }^{124}$ J 19/87; TBoA 20.8.1998, T 833/94, ECLI:EP:BA:1998:T083394.19980820; TBoA 15 March 2005, T 74/00 (Scanning Confocal Endoscope/OPTISCAN), ECLI:EP:BA:2005:T007400.20050315.

125 Teschemacher 1983, p. 699.
} 
Arbeitsgrupe "Patente" (ed) (1962) Ergebnisse der fünften Sitzung der Arbeitsgruppe "Patente" vom 2. bis 18. April 1962 in Brüssel, nr. 3076/IV/62-D, Brussels.

Baque G (2008) CBE - PCT, s.l., CLGB Edition, Lyon

Bartels S (2008) An Abstract or a Causal System. In: Faber W, Lurger B, Rules for the Transfer of Movabels A Candidate for European Harmonisation or National Reforms? Sellier European Law Publishers, Munich

Beck M (2009) Amerikaanse octrooien van Belgische werkgevers in gevaar? Intellectuele Rechten Droits Intellectuels (IR DI), 14/4, pp. 330-336

Borg-Barthet J (2013) Free at Last? Choice of corporate law in the EU following the judgment in Vale. International and Comparative Law Quarterly, 62, pp 503-512

Bremi T (2010a) Traps when transferring priority rights, or When in Rome do as the Romans do: A discussion of some recent European and national case law and its practical implications. epi Information, 1, pp 17-24

Bremi T (2010b) Einreichung von US Provisional Applications und Übertragung von Prioritätsrechten: Einige Fallstricke in der Praxis. sic! Zeitschrift für Immaterialgüter-, Informations- und Wettbewerbsrecht, 4, pp 100-108

Briggs A (2013) The Conflict of Laws, Third Edition. Oxford University Press, Oxford, pp 367373

Drexl J (2005) The Proposed Rome II Regulation. In: Drexl J, Kur A (eds), Intellectual Property and Private International Law: Heading for the Future. Hart Publishing, Oxford Engelen T van (2007) Intellectuele eigendom en internationaal privaatrecht. Boom Juridische Uitgevers, Den Haag

EPO (ed) (2013) Case Law of the Boards of Appeal of the European Patent Office, EPO, Munich

EPO (ed) (2014) Guidelines for Examination in the EPO (November 2014 Edition), EPO, Munich

EPO (ed) (2016) Guidelines for Examination in the EPO (November 2016 Edition), EPO, Munich

Erp S van, Akkermans B (2012) Cases, Materials and Text on Property Law. Bloomsbury Publishing, London 
European Max Planck Group on Conflict of Laws in Intellectual Property (2013) Conflicts of Laws in Intellectual Property, the CLIP Principles and Commentary. Oxford University Press, Oxford

Fawcett J, Torremans P (2011) Intellectual Property and Private International Law, Oxford University Press, Oxford

Govt. of the Federal Republic of Germany (ed.) (1973) Minutes of the Munich Diplomatic Conference for the Setting up of a European System for the Grant of Patents, Munich

Haedicke M, König G (2016) Der Zeitpunkt der Übertragung eines Prioritätsrechts. GRUR Int., $613-621$

Haertel K (1962) Bemerkungen zu dem Ersten Arbeitsentwurf eines Abkommens über ein europäisches Patentrecht, Artikel 23 bis 26 a, 10 February 1962. Bonn

Hinteregger M, Vliet L van (2012), Transfer. In: Erp S van, Akkermans B (eds) (2012) Cases, Material and Text on Property Law, Hart Publishing, Oxford, Chapter 8

Ho D, Molnia, D (2016) Unmittelbar anwendbare Legalzession, Intellectual Property 2: 20-21

Korenberg A (2011) Ensuring Valid Priority Claim for US Originating Application.

http://www.kilburnstrode.com/assets/articles\%20\&\%20briefing\%20notes/Ensuring\%20Valid\%2 0Priority\%20Claims\%20for\%20US\%20Originating\%20Applications.pdf. Accessed 12

December 2016

Mankowski P (2009) Contracts relating to intellectual property or industrial property under the Rome I regulation. In Leible S, Ohly A (eds) Intellectual Property and Private International Law, Mohr Siebeck, Tübingen, pp. 44-46

Metzger A (2005) Transfer of Rights, License Agreements, and Conflict of Laws: Remarks on the Rome Convention of 1980 and the Current ALI Draft. In: Basedow J, Drexl J, Kur A (eds), Intellectual Property in the Conflict of Laws, Mohr Siebeck, Tübingen, pp 61-77

Metzger A (2013) Note under art. 3:501. In: European Max Planck Group on Conflict of Laws in Intellectual Property, Conflicts of Laws in Intellectual Property, the CLIP Principles and Commentary, Oxford University Press, Oxford, pp 270-271

Savigny F C von (1849) System des heutigen Römischen Rechts, 8. Band. Veit und Comp., Berlin 
Schweizer M (2011) Transfer of Priority Rights. http://ipkitten.blogspot.be/2011/02/transfer-ofpriority-rights.html. Accessed 12 December 2016

Stauder D, Luginbühl S (eds) (2013) Singer/Stauder: Europäisches Patentübereinkommen, Karl Heymanns Verlag, Köln

Visser D (2016) The annotated European Patent Convention, 24th edition. H. Tel, Veldhoven Worthington S (2006) Equity, Second Edition. Oxford University Press, Oxford Teschemacher R (1983) Anmeldetag und Priorität im europäischen Patentrecht. GRUR Int., pp $695-702$

Teschemacher R (2016) Aktuelle Rechtsprechung der Beschwerdekammern des EPA - Notizen für die Praxis. Mitteilungen der Deutschen Patentanwälte, 8-9, pp 364-371

Tronson S (2011) Does timing of an assignment document have a substantive effect on patentability? http://www.foundersspace.com/legal-ip/does-timing-of-filing-an-assignmentdocument-have-substantive-effect-on-patentability/. Accessed 12 December 2016 Ulmer E (1978) Intellectual Property Rights and the Conflict of Laws. Kluwer, Deventer Vlas P (2009) Rechtspersonen. Maklu, Apeldoorn/Antwerpen 